\title{
Design and Analysis of Technical Economics of Off-grid Systems Solar Power Plant Using Homer at Cemara Island, Brebes Regency
}

\author{
Jaka Windarta ${ }^{1,2^{*}}$, Denis ${ }^{1}$, Agung Nugroho ${ }^{1}$, and Bimo Bagaskoro ${ }^{1}$ \\ ${ }^{1}$ Department of Electrical Engineering, Faculty of Engineering, Diponegoro University, Semarang-Indonesia \\ ${ }^{2}$ Magister of Energy, School of Postgraduate Studies, Diponegoro University, Semarang- Indonesia
}

\begin{abstract}
Cemara Island is a coastal tourism area that has not been electrified and this problem becomes an obstacle for local residents to use electrical energy services. The impact of the absence of facilities in the form of electrical installations is that coastal tourism activities are not optimal. These Photovoltaic technologies may convert solar energy into electrical energy through photovoltaic effects. For this reason, The Solar power plant can be the solution to the problems in Cemara Island. However, technical and economic analysis is needed. From the result of solar system design calculation, it was obtained the number of solar panel capacity is $8 \times 150 \mathrm{Wp}$, solar charge controller of $40 \mathrm{~A}, 4$ units of battery with $100 \mathrm{Ah}$ specifications, and $2000 \mathrm{~W}$ of the inverter. By using Homer, it can be seen that the amount of power produced by solar panels is $1746 \mathrm{kWh} /$ year. With an initial investment of $\$ 3745$, in the scenario of using interest at $6 \%$, the net present cost is $\$ 6534$, the cost of energy value is $\$ 1,06 / \mathrm{kWh}$, and BEP occurring at 11 th year. Then in the scenario without using interest, the net present cost value is $\$ 8848$, the value of cost of energy is $\$ 0.755 / \mathrm{kWh}$ and BEP occurring at 25 th year.
\end{abstract}

Keywords: Cemara Island; Solar power plant; Off-grid; Economic and Technical Analysis

\section{Introduction}

Energy has an important role in the development process, to achieve social, economic, and environmental goals. The important role of this energy will eventually become a support for the economic community so that it will attract attention to the community. In 2010, many countries have realized the importance of utilizing renewable energy sources as a substitute for nonrenewable energy such as petroleum, coal, and gas which have had a damaging impact on the earth. One of the potential uses of renewable energy sources in Indonesia is the energy from the sun. Indonesia is a country that is geographically located right on the equator and provides a variety of advantages and great potential in terms of solar energy utilization. This is because the amount of solar radiation depends on the location of the latitude, atmospheric conditions, and the position of the sun on the equator [1]. Indonesia has so many small and isolated islands that desperately need electricity. In addition, the distribution of electricity to the area require adequate transportation and high cost. Photovoltaic solar energy is one of the solutions to meet the electricity needs including lighting for the units of public services and the means of worship [2]

In Indonesia, the solar radiation distribution can be divided into Western and Eastern area. This classification based on solar radiation data collected from 18 locations in Indonesia. Distribution of solar radiation is estimated at around $4,5 \mathrm{kWh} / \mathrm{m} 2 /$ day with a monthly variation of about $10 \%$ for the West Region and $5,1 \mathrm{kWh} / \mathrm{m} 2 /$ day with a variation of about $9 \%$ for Eastern Region [2, 3].

Cemara Island is a coastal tourism area that has not been electrified by PLN (Indonesia's Electric Company), this is because the location of Cemara Island is far from the mainland or needs to pass through the estuary first so that PLN has not been able to reach this place. This is an obstacle for local residents to use electrical energy services, with the impact of the absence of facilities in the form of lighting installations and electrical installations so that coastal tourism activities and the region's nature are not optimal.

The solution to this problem is the implementation of a Solar power plant with DC output specifications. DC electrical energy can be obtained directly from sunlight using cell-shaped photovoltaic (PV) devices. These cells convert solar energy into electrical energy through photovoltaic effects. PV cells are extensive p-type diodes that are assembled in a module. Installation in PV has no moving and vibrating parts so it does not produce sound, and installation of PV does not require a cooling tower. There are several factors that affect the output efficiency of solar cells, namely solar radiation, solar cell

\footnotetext{
* Corresponding author: jokowind@yahoo.com
} 
temperature, solar panel orientation, the tilt angle of solar panels, and the influence of shadows [4, 5]. In addition, in the manufacture of solar power plants, economic design and analysis are needed to be able to maximize the performance and to carry out financial calculations from the plants itself. Therefore, based on the background that has been explained, this research will be focused on the design and economic analysis of the solar power plant system.

\section{Discussion}

The sun's energy just over eight minutes to travel the 93 million miles to Earth. Solar energy travels at a speed of 186,000 miles per second [6]. Only a small part of the radiant energy that the sun emits into space ever reaches the Earth, but that is more than enough to supply all our energy needs. Every day enough solar energy reaches the Earth to supply our nation's energy needs for a year. Solar is one of the most promising sources of renewable energy and it has the greatest potential in comparison with other energy sources to solve the world's energy problems [2]. Nowadays, solar energy has become more popular as an energy supply in the world and is considered as the most economical alternative. Solar energy is designed to convert all or any portion of available light into electrical energy. This conversion process does not use a chemical reaction $[2,3]$.

Presidential Decree No. 5 mandates an increase in renewable energy production from 7 percent to 15 percent of generating capacity by 202 . In order to accomplish that goal, $6.7 \mathrm{GW}$ of new renewable energy capacity must be installed in the next 15 years based on current growth projections [7]. The Directorate General of Electricity and Energy Utilization has also promoted green energy which is the union of renewable energy, including solar energy, energy efficiency and clean energy to create sustainable development, in July 2012.

In this research, there are two economic analysis scenarios that used to determine the effect of interest on the value of net present cost (NPC), cost of energy (COE) and break-even point (BEP) [8]. In addition, the design of solar power plants is also taken into account in order to find out the performance of solar power plants in producing electricity every year periodically. This project is using a software called Homer to analyze the outcome of the economic and technical result of the solar power plant. To design solar power plants, some data is needed to calculate the performance of solar power plants. There is some data that will be used to determine the capacity of solar power plants needed on Cemara Island.

\subsection{Solar Radiation and Temperature of Cemara Island}

In this project, data collection is done through the website from NASA (National Aeronautics and Space Administration) to find out various meteorological and climatological parameters in the planning area, namely in the Brebes City region in 2018. The data needed for this final project are as follows:
Table 1. Solar radiation of Cemara Island 2018

\begin{tabular}{|c|c|}
\hline Month & $\begin{array}{c}\text { Solar Radiation } \\
\left.\text { (Kwh/ } \mathbf{m}^{2} \text { /day }\right)\end{array}$ \\
\hline January & 4.42 \\
\hline February & 4.73 \\
\hline March & 5.37 \\
\hline April & 5.15 \\
\hline May & 4.94 \\
\hline June & 4.96 \\
\hline July & 5.49 \\
\hline August & 5.83 \\
\hline September & 5.96 \\
\hline Oktober & 6.11 \\
\hline November & 5.26 \\
\hline December & 4.88 \\
\hline Average & 5.26 \\
\hline
\end{tabular}

Table 2. Average Temperature of Cemara Island 2018

\begin{tabular}{|c|c|}
\hline Month & $\begin{array}{c}\text { Average Temperature } \\
\left({ }^{\mathbf{}} \mathbf{C}\right)\end{array}$ \\
\hline January & 26.35 \\
\hline February & 26.19 \\
\hline March & 26.52 \\
\hline April & 27.02 \\
\hline May & 26.88 \\
\hline June & 26.12 \\
\hline July & 24.83 \\
\hline August & 24.82 \\
\hline September & 26.32 \\
\hline Oktober & 27.49 \\
\hline November & 27.11 \\
\hline December & 26.78 \\
\hline Average & 26.37 \\
\hline
\end{tabular}

\subsection{A Load of Cemara Island}

In the load data collection, a survey is carried out to determine the type of load and duration of usage. Load mapping on Cemara Island consists of 2 conditions, namely weekdays and weekends. Where the number of loads per day on weekdays conditions is $0.82 \mathrm{~kW}$ and weekend conditions are $4.534 \mathrm{~kW}$ with a peak load of 0.5 $\mathrm{kW}$. Because Cemara Island is a tourist spot, so the energy needs during weekdays are quite low and the energy needs during weekends are quite high. This is due to many visitors during weekends. The load used on Cemara Island consists of lights, cellphone chargers, and TV.

\subsection{The Design of Solar power plant System in Cemara Island [9-11]}

\subsubsection{Solar Panel}

The type of solar panel used in solar power plantls design in the Cemara Island Tourism Area uses solar panels with Polycrystalline silicon cell types. As it is known, the lowest irradiation in 2018 is $4.42 \mathrm{kWh} / \mathrm{m} 2$ / day, and it is known that the largest total energy per day of Cemara 
Island is $4.534 \mathrm{~kW}$. Then the capacity requirements of solar modules can be calculated by the following equation

$$
\text { Modul Capacity }=\frac{4,534}{4,42}=1,02 \mathrm{~kW}
$$

With the specifications of a solar panel of $150 \mathrm{Wp}$, it takes 8 solar panels to meet the load requirements on Cemara Island. After knowing the required specification values, a datasheet about the solar panels to be used is needed. Then all those parameters from datasheets are entered into the homer software to run the simulation.

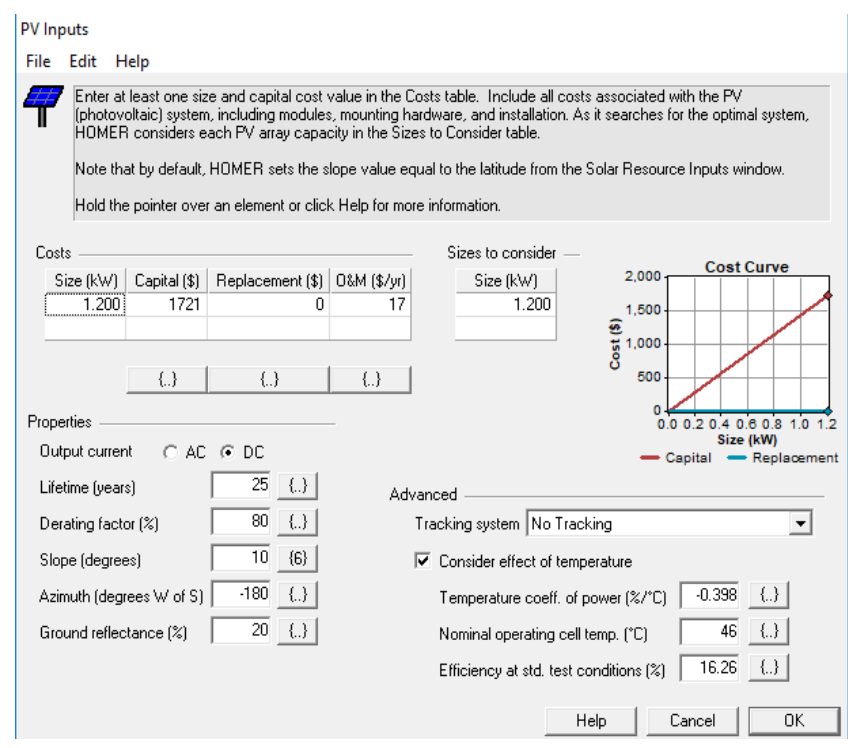

Fig 1. Solar panel input parameters

\subsubsection{Inverter}

The inverter is one of the components of the PV system that needs to be considered. This tool will convert DC (direct current) currents generated from solar panels into AC (alternating current) currents for use by household appliances in general. The inverter that will be used in the design of the solar power system is an off-grid type. Selection of this type of inverter with consideration because the specifications of this inverter have a cut-off system where the inverter will disconnect the circuit with the battery if the battery is out. In addition, the full load condition on Cemara Island is 501 Watts, while this inverter can be used for loads up to 2000 Watt with consideration as a development factor.

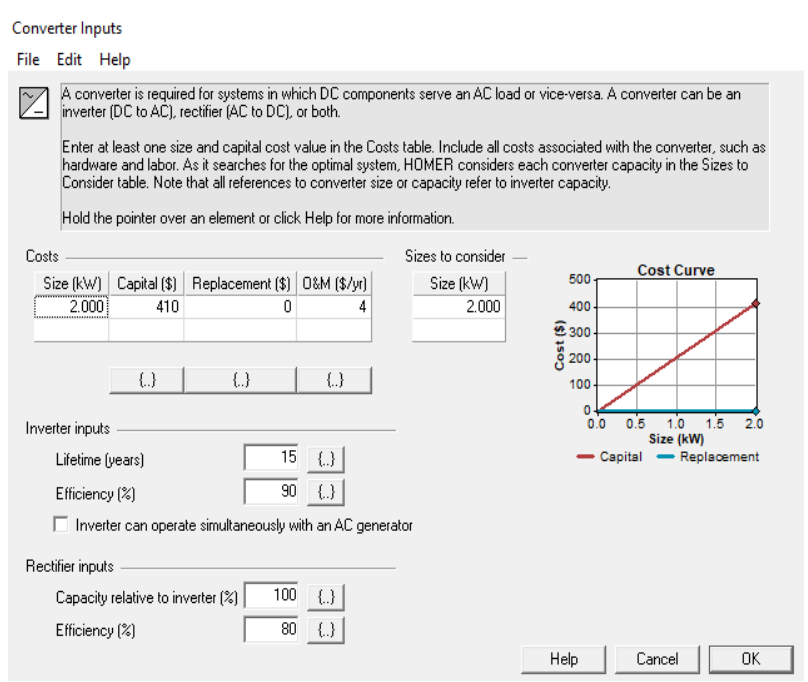

Fig 2. Inverter input parameters

\subsubsection{Baterry}

The battery is a component of a solar power generation system that is quite important in an off-grid solar power plant. This battery serves as a storage device for energy produced by the Solar Panel. Without a battery, the solar power plant can only be used during the day or in the sun shines. To determine the battery capacity, it is necessary to know the approximate amount of energy per day, autonomous days, efficiency, the duration of battery usage per day and the limit of the depth of discharge values. Then use the following equation:

Batt. Capacity $=\frac{\text { Energy per day } x \text { autonomous day }}{\text { Efficiency } \times \text { DoD limit } \mathrm{x} \text { Battery usage }}(2)$

$$
\text { Battery Capacity }=\frac{4.534 \times 2}{0.85 \times 0.25 \times 12}=4,2 \mathrm{kWh}
$$

Therefore, a battery bank with a specification of 4.8 $\mathrm{kWh}$ is used. with details of 4 battery units with a capacity of $100 \mathrm{Ah}$ and have a voltage rating of $12 \mathrm{~V}$

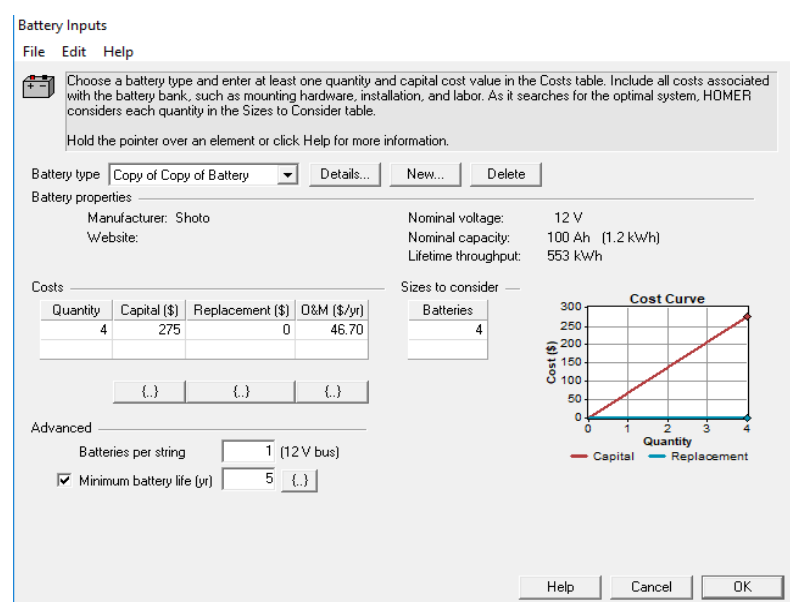

Fig 3. Battery input parameters 


\subsubsection{Solar Charge Controller}

In the field, solar panels always have to change voltage and current values, this is due to the value of solar radiation that is always changing and sometimes not optimal. While charging the battery, a constant voltage and current value are needed. For this reason, the solar charge controller is used to regulate direct current which is charged to the battery so that the voltage and current become constant. Due to the arrangement of the solar module circuit, it produces a current of $35.32 \mathrm{~A}$. So that solar charge controller with a specification of $40 \mathrm{~A}$ is used, so that the output current of the solar module is not greater than the solar charge controller capacity.

\subsubsection{Solar power plant circuit}

After determining the components to be used in the solar power plant, the next stage is the design of the solar power plant installation. The following is a series of solar power plant installations that will be implemented on Cemara Island.

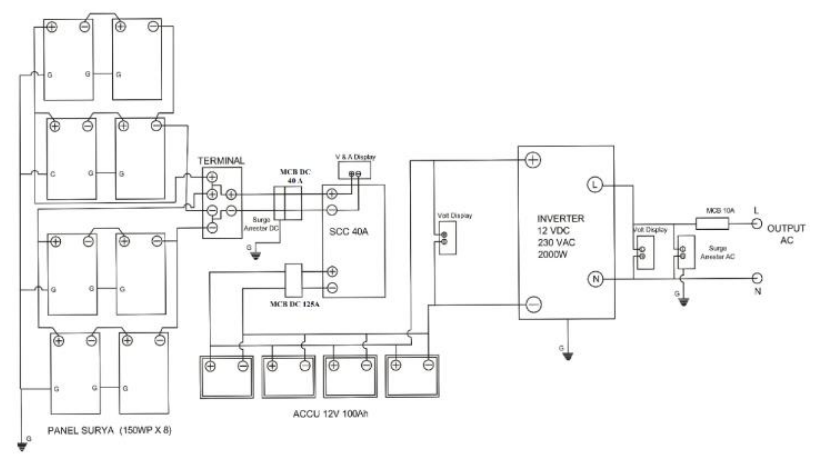

Fig 4. Installation of the Cemara Island Solar power plant

In figure 4 , it can be seen that solar modules are arranged in series-parallel combinations, namely 2 series and 4 parallels. So that with a Voc value of $22.1 \mathrm{~V}$ and Isc of $8.83 \mathrm{~A}$, this solar panel module can produce an output voltage of up to $44.1 \mathrm{~V}$ and $35.32 \mathrm{~A}$. Batteries are installed parallel because the SCC system and the inverter used are $12 \mathrm{~V}$ systems. In addition, the total capacity of the battery becomes 400Ah when parallel-connected so that the storage capacity of the solar power plant will also be greater.

\section{Simulation}

Homer's optimization process was carried out after the simulation process was completed. The initial simulation process aims to determine the optimum variable size in each of the main components installed when operating alone. The simulation results from the solar power plant on the island of Fir in the form of output power from solar panels and the power used can be seen in Figure 5:

\begin{tabular}{|c|c|c|c|c|c|}
\hline Production & kWh/yr & $\%$ & Consumption & kwh/y & $\%$ \\
\hline $\mathrm{PV}$ array & 1,746 & 100 & AC primary load & 469 & 100 \\
\hline Total & 1,746 & 100 & Total & 469 & 100 \\
\hline
\end{tabular}

Fig 5. PV production and load consumption

The difference between PV production and load consumption due to the load used on pine islands is still small, so it needs further development so that PV production can be used more. Then, in the economic analysis in this study two scenarios were used in which scenario 1 uses an interest rate of $6 \%$ per year and scenario 2 is an economic condition not using interest rates. Both of these economic analyzes show the solar power plants project with loan costs and without loan costs.

\subsection{Scenario 1}

Scenario 1 is an analysis scenario on Homer by using an annual interest rate parameter of $6 \%$, so it will produce a different net present cost, cost of energy and break-even points. The following are the results of the homer

\begin{tabular}{|c|c|c|c|c|c|c|c|c|c|}
\hline 再田 & $\begin{array}{c}\mathrm{PV} \\
(\mathrm{kW})\end{array}$ & Energy $C$. & $\begin{array}{l}\text { Conv. } \\
(\mathrm{kW})\end{array}$ & $\begin{array}{l}\text { Intitial } \\
\text { Capital }\end{array}$ & $\begin{array}{l}\text { Operating } \\
\text { Cost (s/yr) }\end{array}$ & $\begin{array}{l}\text { Total } \\
\text { NPC }\end{array}$ & $\begin{array}{c}\text { COE } \\
(S / k W h)\end{array}$ & \begin{tabular}{|l|} 
Ren. \\
Frac.
\end{tabular} & \begin{tabular}{|l|l|}
$\begin{array}{l}\text { Capacity } \\
\text { Shorttage }\end{array}$ & (vr). \\
\end{tabular} \\
\hline 果图 & 1.2 & 4 & 2 & $\$ 3,7$ & 204 & $\$ 6,3$ & 1.061 & 1.00 & 0.35 \\
\hline
\end{tabular}

Fig 6. Homer simulation results

\subsubsection{Net Present Cost (NPC)}

The present total net cost is the main economic output in the solar power plant system in Homer. Homer will calculate the data output from simulation and NPC optimization. With a total cost that must be incurred by the user in implementing the solar power plant system that uses a parameter of interest rates of $6 \%$. During the 25year project period, the total cost to be incurred was $\$$ 6354, equivalent to Rp. 89.173.433,--

\subsubsection{Cost of Energy (COE)}

The cost of energy can be interpreted as the average cost per kWh of the production of electrical energy used by the system. In the Homer simulation, COE is calculated by dividing the annual cost of producing electricity with the total electricity used being produced. In Homer, the COE unit used is $\$ / \mathrm{kWh}$ so that by knowing the COE, it can be seen the electricity tariff and income generated from the sale of energy.

In figure 6 can be seen, the COE value obtained by Homer is $\$ 1,06$ per $\mathrm{kWh}$ or equivalent to Rp. 14.890 ,- per $\mathrm{kWh}$ at the dollar exchange rate against the rupiah of Rp. 14,034.22. By knowing the value of COE, it can be seen that the income earned within a year by doing $\mathrm{COE}$ multiplication with the total electrical energy used in a year. Then from this multiplication, the income per year is obtained as follows: 


$$
\begin{aligned}
\text { Electricity sales per year } & =\text { COE } \times \text { AC Load } \\
& =\$ 1,06 / \mathrm{kWh} \times 469 \\
& =\$ 497,14
\end{aligned}
$$

However, this income is still a gross income, or income that has not been reduced by operational and maintenance costs.

\subsubsection{Break Even Point (BEP)}

Break even point is a condition where the value of investment and income is at point 0 , or it can be said that it is in a condition not experiencing a loss and not experiencing a profit. The BEP value is needed to be able to estimate in what year investors begin to experience profits. Because Homer's software does not calculate BEP values, manual calculations are used. The parameter needed to calculate BEP is fixed cost, coe and variable cost, where variable cost is the cost needed to produce 1 $\mathrm{kWh}$ that can be obtained by divided O\&M cost per year with load consumption per year. By knowing the average operational and maintenance costs, BEP values can be calculated and with the following parameters:

$$
\begin{array}{ll}
\text { Fixed Cost } & =\$ 3745 \\
\text { COE } & =\$ 1,06 / \mathrm{kWh} \\
\text { Variable Cost } & =\$ 104,36 / 469=\$ 0.222
\end{array}
$$

$$
B E P(\text { unit })=\frac{3745}{1,06-0,222}=4468,9 k W h
$$

From these calculations, it can be seen to get a capital turnover or BEP, so the sale of power is needed at 4468,9 $\mathrm{kWh}$. Whereas to find out the income that needs to be received so that the BEP occurs, the following equation is used:

$$
\begin{aligned}
\text { Income when BEP } & =\mathrm{BEP}(\text { Unit }) \times \mathrm{COE} \\
& =\$ 4737,11
\end{aligned}
$$

So that the income that needs to be received in order for the BEP to occur is $\$ 4737,11$ with an annual income of $\$ 497,14$ and a BEP value achieved in the $11^{\text {th }}$ year.

\subsection{Scenario 2}

Scenario 2 is an analysis scenario on Homer by not using an annual interest rate. So it will produce a different net present cost, cost of energy and break-even points. The following are the results of the homer.

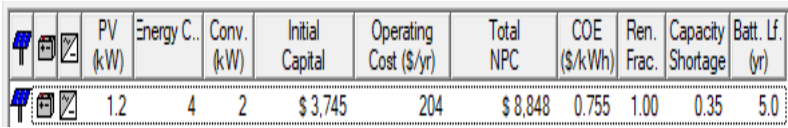

Fig 7. Homer simulation results

\subsubsection{Net Present Cost (NPC)}

The present total net cost is the main economic output in the solar power plant system in Homer. Homer will calculate the data output from simulation and NPC optimization. With a total cost that must be incurred by the user in implementing the solar power plant system that uses a parameter of interest rates of $0 \%$. During the 25 year project period, the total cost to be incurred was $\$$ 8.848 equivalent to Rp. 124.174 .779 ,-.

\subsubsection{Cost of Energy (COE)}

In figure 7 can be seen, the COE value obtained by Homer is $\$ 0.755$ per $\mathrm{kWh}$ or equivalent to Rp. 10.595 ,- per $\mathrm{kWh}$ at the dollar exchange rate against the rupiah of $\mathrm{Rp}$. 14,034.22. By knowing the value of COE, it can be seen that the income earned within a year by doing COE multiplication with the total electrical energy used in a year. Then from this multiplication, the income per year is obtained as follows:

$$
\begin{aligned}
\text { Electricity sales per year } & =\text { COE } \times \text { AC Load } \\
& =\$ 0.755 / \mathrm{kWh} \times 469 \\
& =\$ 354,1
\end{aligned}
$$

However, this income is still a gross income, or income that has not been reduced by operational and maintenance costs.

\subsubsection{Break Even Point (BEP)}

Break even point is a condition where the value of investment and income is at point 0 , or it can be said that it is in a condition not experiencing a loss and not experiencing a profit. The BEP value is needed to be able to estimate in what year investors begin to experience profits. Because Homer's software does not calculate BEP values, manual calculations are used. The parameter needed to calculate BEP is fixed cost, coe and variable cost, where variable cost is the cost needed to produce 1 $\mathrm{kWh}$ that can be obtained by divided O\&M cost per year with load consumption per year. By knowing the average operational and maintenance costs, BEP values can be calculated and with the following parameters:

$$
\begin{aligned}
& \begin{array}{ll}
\text { Fixed Cost } & =\$ 3745 \\
\text { COE } & =\$ 0.755 / \mathrm{kWh} \\
\text { Variable Cost } & =\$ 204 / 469=\$ 0.434 \\
\qquad \text { BEP (unit) } & =\frac{3745}{0,755-0,434}=11.666 \mathrm{kWh}
\end{array}
\end{aligned}
$$

From these calculations, it can be seen to get a capital turnover or BEP, so the sale of power is needed at $11.666,7 \mathrm{kWh}$. Whereas to find out the income that needs to be received so that the BEP occurs, the following equation is used:

$$
\begin{aligned}
\text { Income when BEP } & =\mathrm{BEP}(\text { Unit }) \times \mathrm{COE} \\
& =\$ 8.808,3
\end{aligned}
$$

So that the income that needs to be received in order for the BEP to occur is $\$ 8.808,3$, with an annual income of $\$ 354,1$ and a BEP value achieved in the 25 th year. 


\section{Conclusion}

The solar power plant system designed in the planning of the Cemara Island Solar power plant is a generating system that is not connected to any power plant (off-grid). This solar power plant system uses $8 \times 150 \mathrm{Wp}$ of PV, 4 units of $12 \mathrm{~V} / 100 \mathrm{Ah}$ battery and inverter $2000 \mathrm{~W}$. So that electricity is obtained at $1,746 \mathrm{kWh} /$ year, where Cemara Island's electrical energy consumption is 469 $\mathrm{kWh} /$ year.

In the economic analysis of scenario 1 with an interest rate of $6 \%$, the simulation results obtained with an NPC value of $\$ 6354$ or Rp. 89.173.433,- and COE of \$1,06 / $\mathrm{kWh}$ or Rp 14.890,- / $\mathrm{kWh}$. By knowing the value of $\mathrm{COE}$, it can be seen that the income earned per year is $\$$ 497,14 / year or IDR 6.976.972,-. (Dollar exchange rate $=$ Rp. 14,034.22).

Break-even point from the results of economic analysis of scenario 1 occurred in $\mathrm{kWh}$ sales of 4.468,9 $\mathrm{kWh}$ with a revenue of $\$ 4.737,11$. So by looking at the income table per year, it can be seen that the capital turnover of solar power plant scenario 1 occurred in the 11 th year.

In the economic analysis of scenario 2 without interest rates, the simulation results with NPC values of $\$ 8,848$ or equivalent to IDR 124.174.779,- and COE \$ 0.755/ $\mathrm{kWh}$ or IDR $10.595,-/ \mathrm{kWh}$ are obtained. By knowing the value of $\mathrm{COE}$, it can be seen that the income earned per year is $\$ 354,1$ / year or IDR 4.969.517,-/ year. (Dollar exchange rate $=$ Rp. 14,034.22)

The turning point from the results of the economic analysis of scenario 2 occurs in $\mathrm{kWh}$ sales of $11,666,7$ $\mathrm{kWh}$ with a revenue value of $\$ 8.808,3$. So by looking at the income table per year, it can be seen that the capital turnover of solar power plant scenario 2 occurred in the 25 th year.

\section{References}

1. J.A. Duffie, W.A. Beckman, Solar Engineering of Thermal Processes 3th, Jon Wiley \& Sons Inc, New Jersey (2006)

2. S. Mekhilefa, R. Saidurb, A. Safari, A Review on Solar Energy Use in Industries, Renewable and Sustainable Energy Reviews (2011)

3. D. Setiawan, S.F. Mufida, N.Z. Suchesdian, Potential of Renewable Energy : Solar, Water, and Wind in Indonesia as a Alternative Energy on Climate Change Mitigation, Solo: International Seminar on Climate Change Environment Insight for Climate Change Mitigation (2011)

4. Berenguel, Camacho, Rubio, Martinez, Control of Solar Energy Systems, Springer (2012)

5. King, Boyson, Kratochvil, Analysis of Factors Influencing The Annual Energy Production of Photovoltaic Systems, IEEE (2002)

6. Promotion of renewable energy, energy efficient and greenhouse gas abatement, Jakarta, Indonesia (2003)

7. U.S. Department of Commerce International Trade Administration Renewable Energy Market Assessment Report: Indonesia (2011)

8. S. Edition, T. Au, Engineering Economics for Capital Investment Analysis (2005)

9. ABB, Technical Application Papers No.10 Photovoltaic Plants, Bergamo Italy (2008)

10. B. Ramadhani, Dos \& Don'ts, Jakarta: Deutsche Gesellschaft für Internationale Zusammenarbeit (2018)

11. Legha, M. Mozzaffari, Energy and Economic Evaluation of Solar Photovoltaic Plants in Kerman City, Journal of Engineering Research and Application, ISSN :2248-9622 3(5), (2013) 